\title{
Erratum to: A forgotten strand of reception history: understanding pure semantics
}

\section{Peter Olen ${ }^{1}$}

\section{Erratum to: Synthese DOI 10.1007/s11229-015-0678-4}

The last two block quotes of this article should be cited as "Sellars 1947c", not "Sellars 1947". "Sellars 1947c" references the bibliography entry for a piece of correspondence housed in the special collections archive at the University of Iowa. It is not, as the bibliography lists, a published work.

The online version of the original article can be found under doi:10.1007/s11229-015-0678-4.

$\bowtie \quad$ Peter Olen

peterolen@gmail.com

1 Department of Philosophy, University of Central Florida, P.O. Box 1352, Orlando, FL 32816, USA 